\title{
WADAH KOMUNITAS GOTONG ROYONG CBS
}

\author{
Bryan Marco Wijaya ${ }^{1)}$, Petrus Rudi Kasimun ${ }^{2}$
}

1)Program Studi S1 Arsitektur, Fakultas Teknik, Universitas Tarumanagara, bryanmarcowijaya@gmail.com

2)Program Studi S1 Arsitektur, Fakultas Teknik, Universitas Tarumanagara,rudi.kasimun@gmail.com

\begin{abstract}
Abstrak
Proyek yang berlokasi di Kelurahan Cipinang Besar Selatan (CBS) ini menjadi sebuah prototype bagi kehidupan sehari-hari dari masyarakat perkampungan CBS, dimana "komunitas" dan "gotong royong" adalah esensi dasar yang dipegang teguh oleh masyarakat sekitar. Esensi dari "komunitas" dan "gotong royong" dapat secara nyata dilihat apabila melihat kondisi existing pada perkampungan CBS, dimana mereka bergotong-royong membangun kegiatan-kegiatan positif pada kampung mereka seperti; Kampung Bebas Asap Rokok Pertama di Jakarta, Kampung Warna Warni, Kampung Listrik Indie. Namun kegiatan-kegiatan positif terbentuk secara tidak merata pada perkampungan CBS. Hal itulah yang berusaha diselesaikan dalam desain yakni tentang bagaimana Wadah Komunitas Gotong Royong CBS dapat menjadi sebuah Third Place yang bukan saja hanya menjadi wadah untuk melakukan rutinitas dan aktivitas, tetapi menjadi sarana hiburan dan juga edukasi bagi masyarakat $\mathrm{CBS}$, sehingga perkampungan CBS dapat tumbuh maju dan berkembang bersama-sama. Program yang diusung pun sesuai dengan aktivitas sehari-hari masyarakat CBS, sehingga Wadah Komunitas Gotong Royong CBS bukan hanya sebuah wadah, namun menjadi pusat bagi aktivitas-aktivitas perkampungan CBS yang selama ini terpisah satu dengan lainnya. Masyarakat pun bukan hanya menjadi pengguna program, namun mereka dilibatkan sejak awal pembangunan seperti halnya perakitan material utama pada desain yakni Glulam Timber dengan sistem modular, hingga dengan tahap pengelolaan. Begitu juga dengan beberapa aspek lainnya, sehingga dapat dikatakan Wadah Komunitas Gotong Royong CBS bukan saja hanya dapat menjawab esensi dari "komunitas" dan "gotong royong", namun juga menjawab tantangan dari Third Place itu sendiri.
\end{abstract}

\section{Kata kunci: Cipinang Besar Selatan; gotong royong; komunitas}

\begin{abstract}
The project, which is located in Cipinang Besar Selatan (CBS) sub-district, has become a prototype of the CBS community's daily life. "Community" and "mutual cooperation" are the basic essences held by the local society and these essences can be clearly seen from the existing conditions in the CBS village. They work together to build positive activities in their village such as; The First Smoke-Free Village in Jakarta, "Kampung Warna Warni", "Kampung Listrik Indie". However, these activities were formed unevenly in the CBS village. This problem is tried to be resolved through a design that has been proposed. The design is about how the CBS Mutual Cooperation Community could become a Third Place that is not only a place to carry out routines and activities. It also can become an entertainment facility and education for the CBS community. As a result, the CBS community could grow forward and develop together. The program is arranged in accordance to the daily activities of the CBS community. Therefore, the CBS Mutual Cooperation Community may become a center for the village activities that has been separated from each other. The society will not only be participating in the program, but they are involved in its development, like assembling the main material in the design of Glulam Timber with a modular system, up to the management stage. As well as the other aspects, it can be said that the CBS Gotong Royong Community Forum not only answer the essence of "community" and "mutual cooperation", but also answers the challenges of the Third Place itself.
\end{abstract}

Keywords: Cipinang besar selatan; community; mutual cooperation 


\section{PENDAHULUAN \\ Latar Belakang}

Dikarenakan setiap kawasan memiliki permasalahan dan kebutuhan yang berbeda-beda, metode pemilihan kawasan terlebih dahulu dilaksanakan sebelum memilih dan menentukan isu dari kawasan terkait. Dalam hal ini, kawasan perkampungan pada Kelurahan Cipinang Besar Selatan, Kecamatan Jatinegara, Jakarta Timur dipilih, dimana salah satu kampung di kawasan yakni Kampung Penas Tanggul yang sempat viral pada beberapa waktu lalu dikarenakan kawasan tersebut menerapkan beberapa konsep positif dan juga unik dengan dukungan penuh dari seluruh warga yang tinggal di daerah tersebut sehingga menampilkan esensi "komunitas" dan juga "gotong royong". Esensi dari "komunitas" dan "gotong royong" dapat secara nyata dilihat apabila melihat kondisi existing pada perkampungan Cipinang Besar Selatan, atau yang selanjutnya disingkat menjadi CBS, dimana mereka bergotong-royong membangun kegiatankegiatan positif pada kampung mereka seperti; Kampung Bebas Asap Rokok Pertama di Jakarta, Kampung Warna Warni, Kampung Listrik Indie.

Namun kegiatan-kegiatan positif terbentuk secara tidak merata pada perkampungan CBS. Hal itulah yang berusaha diselesaikan dalam desain yakni tentang bagaimana desain dapat menjadi sebuah Third Place yang bukan saja hanya menjadi wadah untuk melakukan rutinitas dan aktivitas, tetapi menjadi sarana hiburan dan juga edukasi bagi masyarakat CBS, sehingga perkampungan CBS dapat tumbuh maju dan berkembang bersama-sama. Hal-hal tersebut merupakan faktor-faktor yang membuat kawasan ini mempunyai daya tarik dan juga karakteristik yang kuat. Hal-hal di atas juga tidak mungkin terjadi tanpa ada-nya aktifnya partisipasi dan rasa persaudaraan yang tinggi dalam kampung tersebut. Warga di sini ingin membuktikan bahwa mereka "tidak layak" untuk digusur dengan menunjukkan hal-hal positif kepada pemerintah.

\section{Rumusan Permasalahan}

Rumusan masalah yang timbul adalah program apa saja yang dibutuhkan untuk menunjang aktivitas dan memenuhi kebutuhan masyarakat Cipinang Besar Selatan serta bagaimana Third Place dapat mewadahi fasilitas dan kebutuhan masyarakat Cipinang Besar Selatan agar memiliki kualitas hidup yang lebih baik?

\section{Batasan Masalah}

Ruang lingkup dalam penulisan ini untuk menentukan fokus pada tema dan permasalahan, dimana Kelurahan Cipinang Besar Selatan merupakan variabel tetap sebagai subjek yang diamati. Masyarakat dan aktivitasnya merupakan variabel bebas yang akan mendukung dan berhubungan langsung dengan variabel tetap. Ruang-ruang sosial dan komunal sebagai variabel bebas kedua yang menjembatani antar penduduk di sana.

\section{Tujuan}

Tujuan dari proyek ini adalah untuk mengembangkan potensi luar biasa dan menyempurnakan program yang saat ini hanya dirasakan oleh sebagian kecil masyarakat yang diwadahi melalui sebuah Third Place, yang diharapkan dapat berdampak dan juga dirasakan manfaatnya secara merata oleh seluruh masyarakat pada Kelurahan Cipinang Besar Selatan. Sehingga masyarakat di Kelurahan Cipinang Besar Selatan dapat saling berinteraksi, mengembangkan potensi dan meningkatkan kreatifitas mereka agar Kelurahan Cipinang Besar Selatan menjadi hidup dan dinamis serta membantu masyarakat menjadi pribadi yang lebih humanis dan produktif.

\section{KAJIAN LITERATUR}

\section{Definisi Space and Place}

Tuan (1977) berpendapat bahwa ruang lebih abstrak dari tempat. Pendapat ini didasarkan pada kondisi dimana setelah mengalami sebuah ruang, maka individu bisa menangkap nilai - 
nilai yang hadir di ruang tersebut. Dengan kata lain tempat ditentukan berdasarkan suatu kondisi tertentu yang hadir di sebuah ruang. Ini berarti tempat hanya bisa hadir apabila ada ruang sebagai dasar pembentukannya.

\section{Definisi Third Place}

Oldenburg (1989) dalam bukunya yang berjudul "The Great Good Place" mengatakan bahwa The Third Place merupakan tempat ketiga yang dibutuhkan oleh masyarakat selain First Place (Tempat Tinggal) dan Second Place (Tempat Kerja). The Third Place juga merupakan sebuah tempat informal yang dijadikan sebagai tempat untuk berkumpul,berinteraksi,dan bersosialisasi antara sesama manusia dengan tujuan agar manusia dapat menjadi pribadi yang lebih humanis dan peduli terhadap sesamanya.

\section{METODE}

Metode perancangan yang digunakan dalam perancangan ini :

a. Studi Literatur Literatur disarikan dari Yi Fu Tuan (1977) dan Oldenburg (1989). Sebagai dasar teoritis untuk dasar konsep pemikiran dan mengetahui esensi dasar dari Third Place

b. Studi preseden Sebagai pembanding antara proyek. Studi preseden yang dipakai adalah; Enabling Village, Seoul Urban Womb, Kampung Admiralty, dan The Planting Terrace and The Experience Pavillion

c. Pengamatan lingkungan Lokasi: Kelurahan Cipinang Besar Selatan. Waktu: Pagi - Sore dan Malam

d. Metode perancangan Analisis hasil studi literatur, survey lapangan dan preseden. Menghasilkan program ruang dari hasil analisis. Konsep Komunitas dan Gotong Royong menjadi acuan dasar dari perancangan. Metode Diagramatik sebagai metode penyajian

e. Hasil perancangan

Hasil perancangan menjadi sebuah wadah bagi masyarakat Cipinang Besar Selatan untuk belajar dan juga beraktivitas, sesuai dengan esensi dasar yang dipegang yakni, esensi komunitas dan juga esensi gotong royong

\section{DISKUSI DAN HASIL}

\section{Konsep Perancangan}

Analisis konsep dan bentuk rancangan menggunakan metodelogi diagramatik dan juga ilustrasi sehingga konsep dapat dilihat baik secara vertikal maupun horizontal. Esensi "komunitas" dan "gotong royong" diangkat menjadi konsep utama setelah analisis kegiatan diilustrasikan, sebagai berikut. 


\begin{tabular}{|c|c|c|c|c|c|}
\hline \multirow{2}{*}{ KODE RUANG } & \multirow{2}{*}{$\begin{array}{c}\text { LOKASI KEGIATAN } \\
\text { (CIPINANG BESAR SELATAN) }\end{array}$} & \multirow{2}{*}{$\begin{array}{l}\text { ILUSTRASI KEGIATAN } \\
\text { (EXISTING) }\end{array}$} & \multirow{2}{*}{$\begin{array}{c}\text { POLA KEGIATAN } \\
\& \\
\text { DESKRIPSI } \\
\end{array}$} & WAKTU KEGIATAN & \multirow{2}{*}{ IMPLEMENTASI DESAIN } \\
\hline & & & & 000 whe 10000 & \\
\hline A & 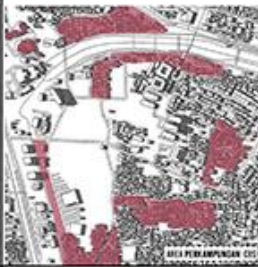 & & $\begin{array}{l}\text { NONTON BARENG } \\
\text { NONTON BAREMG MENJAOI SALAH } \\
\text { SATU KEGATRA UTAMA CENDERUNG } \\
\text { PAOA SORE HINGGA MALAM HARI } \\
\text { BAGI MASYARAKAT CIPINANG BESAR } \\
\text { SELATAN (TERUTAMA SAAT ROMOA) }\end{array}$ & $\begin{array}{c}\text { SENIN - MINGGU } \\
17.00-00.00 \text { (UMUM) } \\
\& \\
00.00-06.00 \text { (RONDA) }\end{array}$ & \\
\hline B & 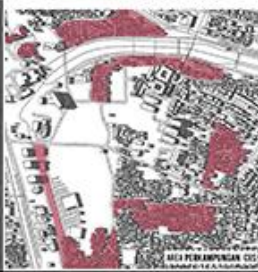 & & $\begin{array}{l}\text { AREA KOMUNAL } \\
\text { JALANAN OEPAN RUMAH YANG } \\
\text { SEMPIT MENJADI RUANG KOMUHAL } \\
\text { YANG BERSIFAT FLEXSIBEL BAGI } \\
\text { MASYARAXAI KAMPUNG OI CBS } \\
\text { UWTUK MENGHABISKAN WAKTU }\end{array}$ & $\begin{array}{l}\text { SENIN - MINGGU } \\
08.00-20.00\end{array}$ & \\
\hline C & 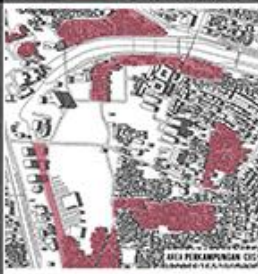 & & $\begin{array}{l}\text { AKTIVITAS IBU-ANAK } \\
\text { IBU DAN JUGA ANAK MERUPAKAN } \\
\text { SATU KESATUA KOMURITAS } \\
\text { OIMANA AKTIVITAS BAGI KEOUA } \\
\text { KELOMPOK TERSEBUT HARUS } \\
\text { TERKONEKSI SATU SAMA LAIN }\end{array}$ & $\begin{array}{c}\text { SENIN - MINGGU } \\
14.00-20.00\end{array}$ & \\
\hline D & 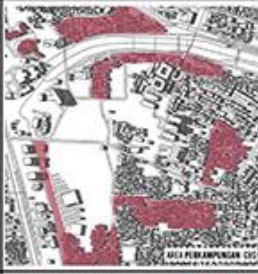 & & $\begin{array}{l}\text { MAIN CATUR \& KARTU } \\
\text { SORE MENUELANG MALAM MENJAOI } \\
\text { WAKTU PALING OISUKAI OLEH BAPAK } \\
\text { BAPAK UNTUK BERKUMPUL DAN } \\
\text { BERMAIN CATUR \& KARTU BERSAMA } \\
\text { (TERUTAMA SAAT RONOA) }\end{array}$ & $\begin{array}{c}\text { SENIN - MINGGU } \\
17.00-23.00 \text { (UMUM) } \\
\& \\
23.00-06.00 \text { (RONDA) }\end{array}$ & $\bar{E}$ \\
\hline $\mathrm{E}$ & 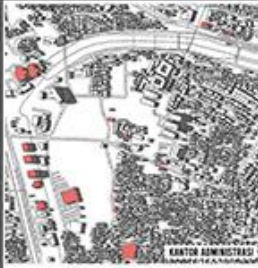 & & $\begin{array}{l}\text { OIBUTUHKAN AULA / TITIK KUMPUL } \\
\text { BAGI MASYARAKAT CIPINANG BESAR } \\
\text { SELUTAN, BAIK UNIUK PERTEMUAN } \\
\text { FORMAL MAUPUN INFORMAL YANG } \\
\text { BERSIFAT INOEPENOEN }\end{array}$ & $\begin{array}{c}\text { SABTU / MINGGU } \\
08.00-11.00 \\
15.00-18.00 \\
\end{array}$ & ค \\
\hline
\end{tabular}

Gambar 1. Diagram Aktivitas di Cipinang Besar Selatan

Sumber : Penulis, 2020 


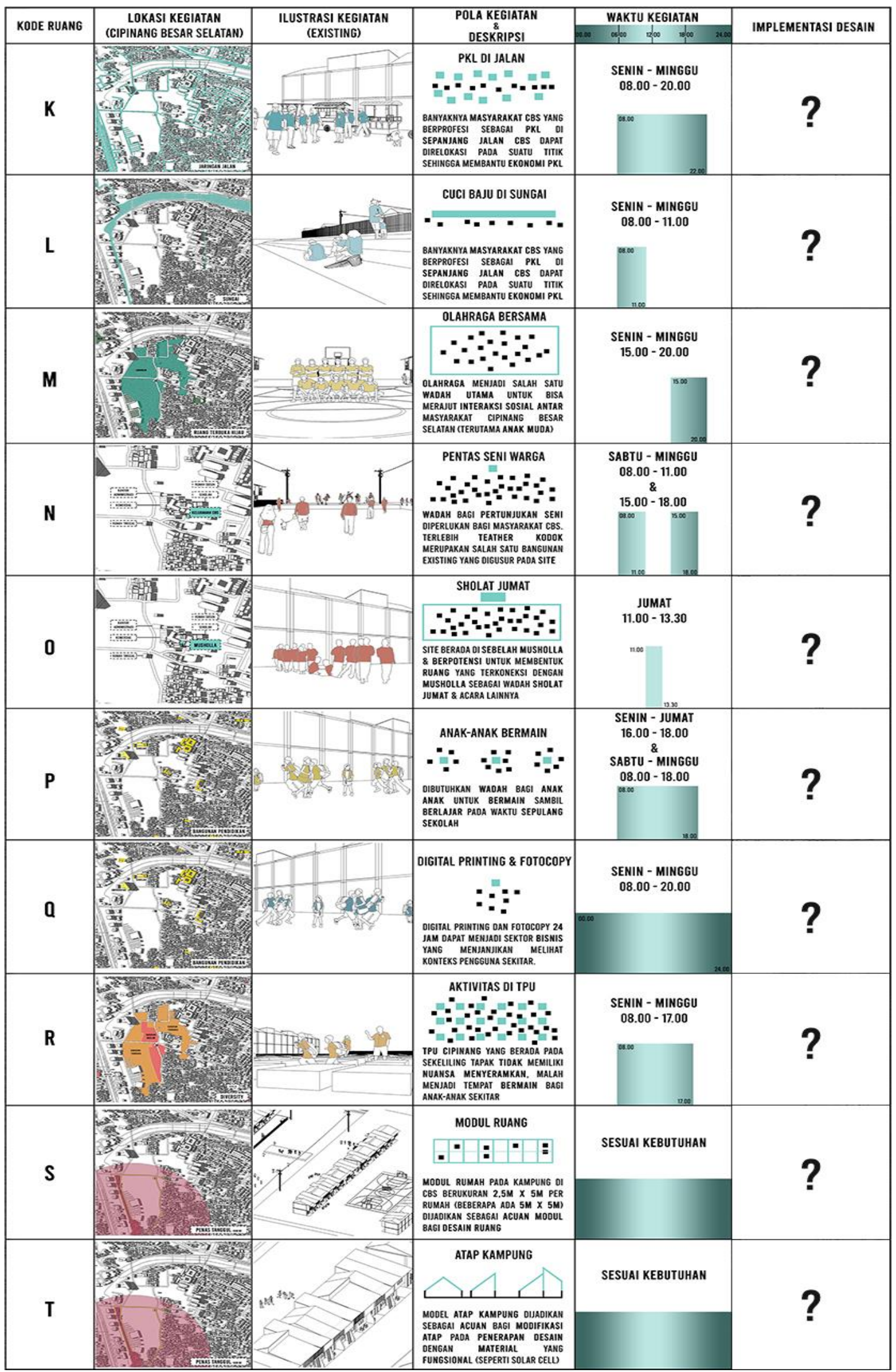

Gambar 2. Diagram Aktivitas di Cipinang Besar Selatan Sumber : Penulis, 2020 


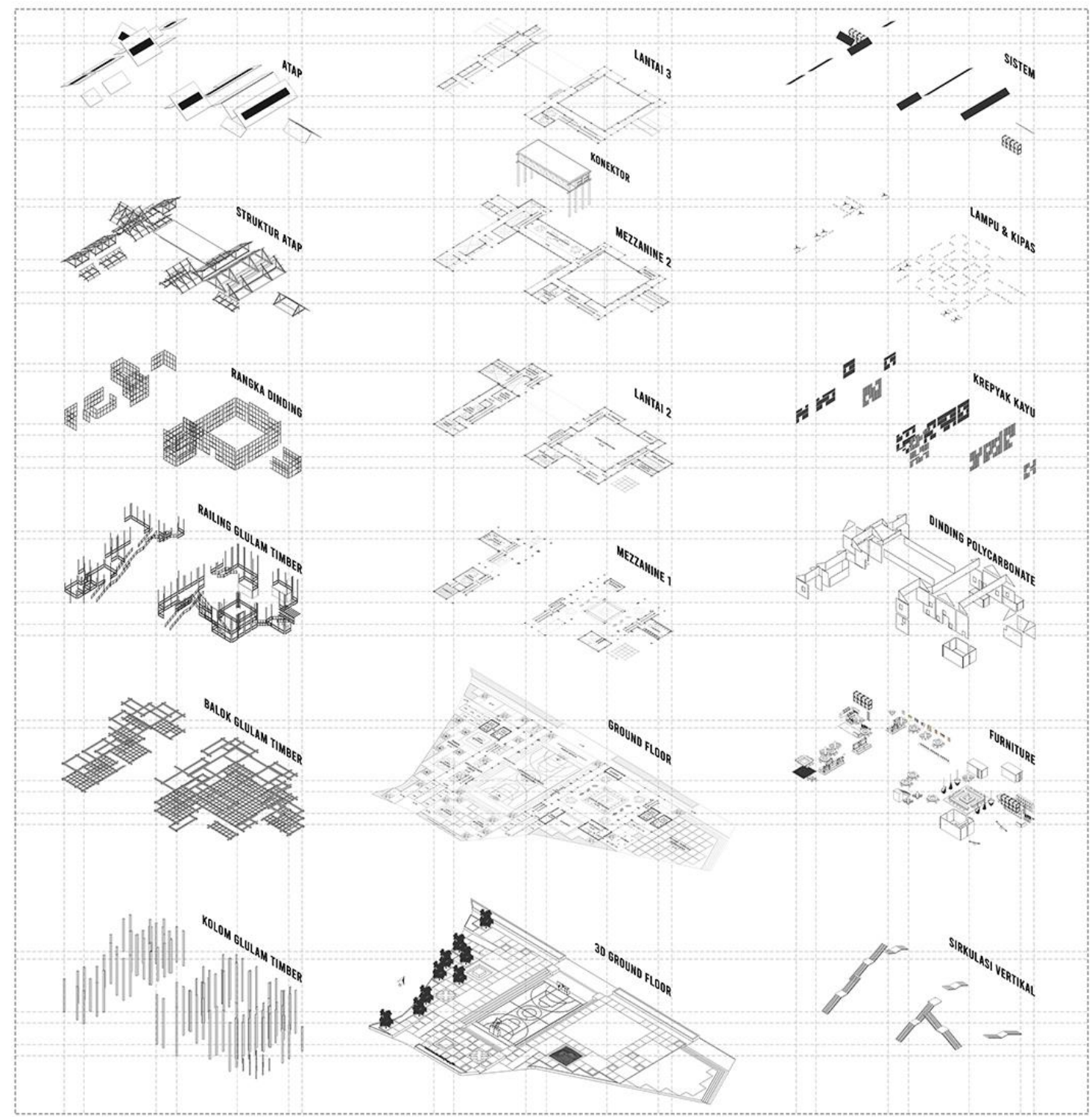

Gambar 3. Axonometri Explode

Sumber : Penulis, 2020

Penyajian gambar dalam bentuk axonometri explode dapat menjelaskan secara paday dan ringkas tentang bagaimana tiap komponen seperti; denah tiap lantai, material, struktur, rangka, furniture, sirkulasi vertikal, dan lain lain terhubung satu dengan lainnya. Secara garis besar desain dengan modul kelipatan $2,5 \mathrm{~m}$ dan seterusnya diangkat menjadi modul pembentuk ruang dimana modul kelipatan $2,5 \mathrm{~m}$ sesuai dengan konteks hunian kampung CBS.

\section{Program}

Program yang telah dianalisis dari segi pola, waktu, pelaku kegiatan dapat dijabarkan sesuai dengan kategori, dan juga penambahan luasan ruang sesuai dengan konteks kebutuhan desain. 
LUASAN

Tabel 1. Program Ruang Proyek

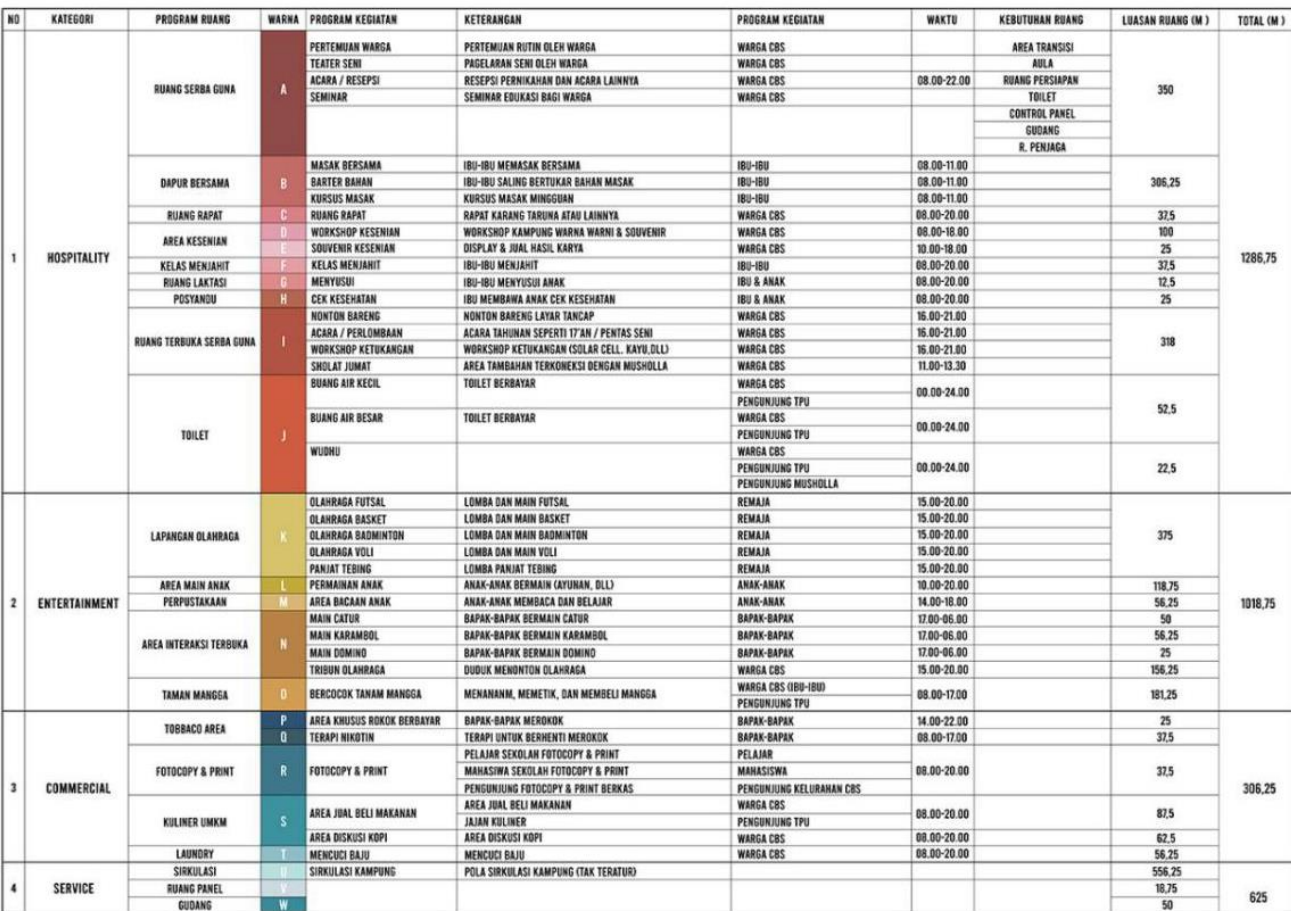

Sumber : Penulis, 2020

\section{PROGRAM RUANG}

POT A-A
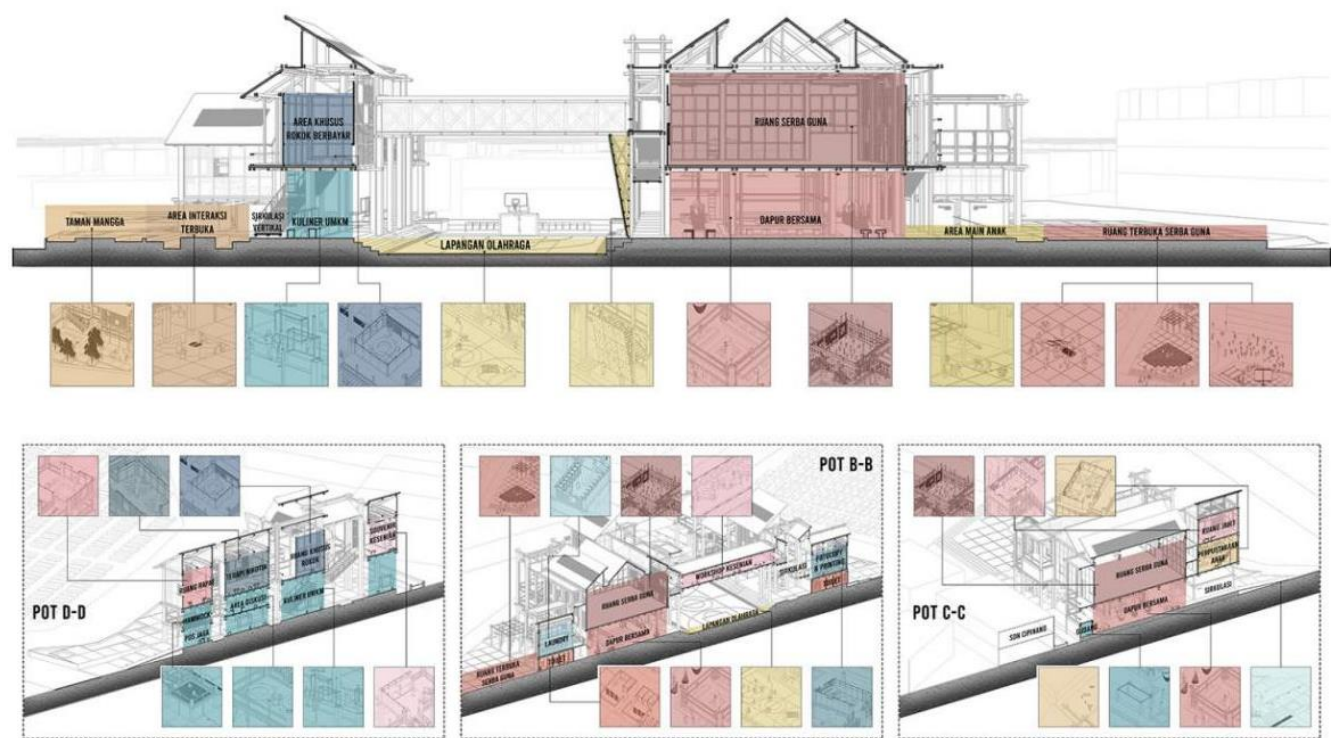

Gambar 4. Program Secara Horizontal dan Vertikal Sumber : Penulis, 2020

Diagram pada potongan perspektif serta potongan axonometri dapat memberikan gambaran terkait hubungan ruang baik vertikal, maupun horizontal. Keterkaitan antar ruang disusun berdasarkan kesamaan kategori yakni antara Hospitality, Entertainment, dan juga Commercial. Selain itu kesamaan faktor pola, waktu, dan pelaku dari kegiatan pun menjadi salah satu faktor bagi penyusunan program. Desain ruang pada massa bagian barat didominasi oleh program 
yang bersifat komersial, hal ini dikarenakan bagian barat merupakan bagian yang ter-ekspos kepada akses utama site yakni TPU Cipinang dan juga Jl. Kebon Nanas, sehingga tentu saja program-program komersial ini dapat dijadikan sebagai daya tarik terhadap masyarakat CBS dan juga pendatang dari luar kawasan CBS. Semua hasil keuntungan dari program komersial digunakan untuk pengelolaan operasional dan pemeliharaan dari Wadah Komunitas Gotong Royong itu sendiri. Sementara pada area terbuka yang notabene diposisikan sesuai dengan respon terhadap konteks SDN Cipinang, didominasi oleh program entertainment, yang rutin digunakan oleh masyarakat CBS pada waktu-waktu tertentu. Dimana pelaku kegiatan dari area terbuka ini dapat dikatakan sebagai pelaku rutin / harian seperti; bapak-bapak bermain catur, anak-anak bermain ayunan, anak muda yang berolahraga, dan lain lain.

\section{Implementasi Third Place}

Desain pun tetap mengacu kepada tujuh esensi dasar dari Third Place menurut Ray Oldenburg, yakni: Neutral, Leveled, Conversation, Accessibled, Have Regulars, Low Profiled, The Mood is Playful.

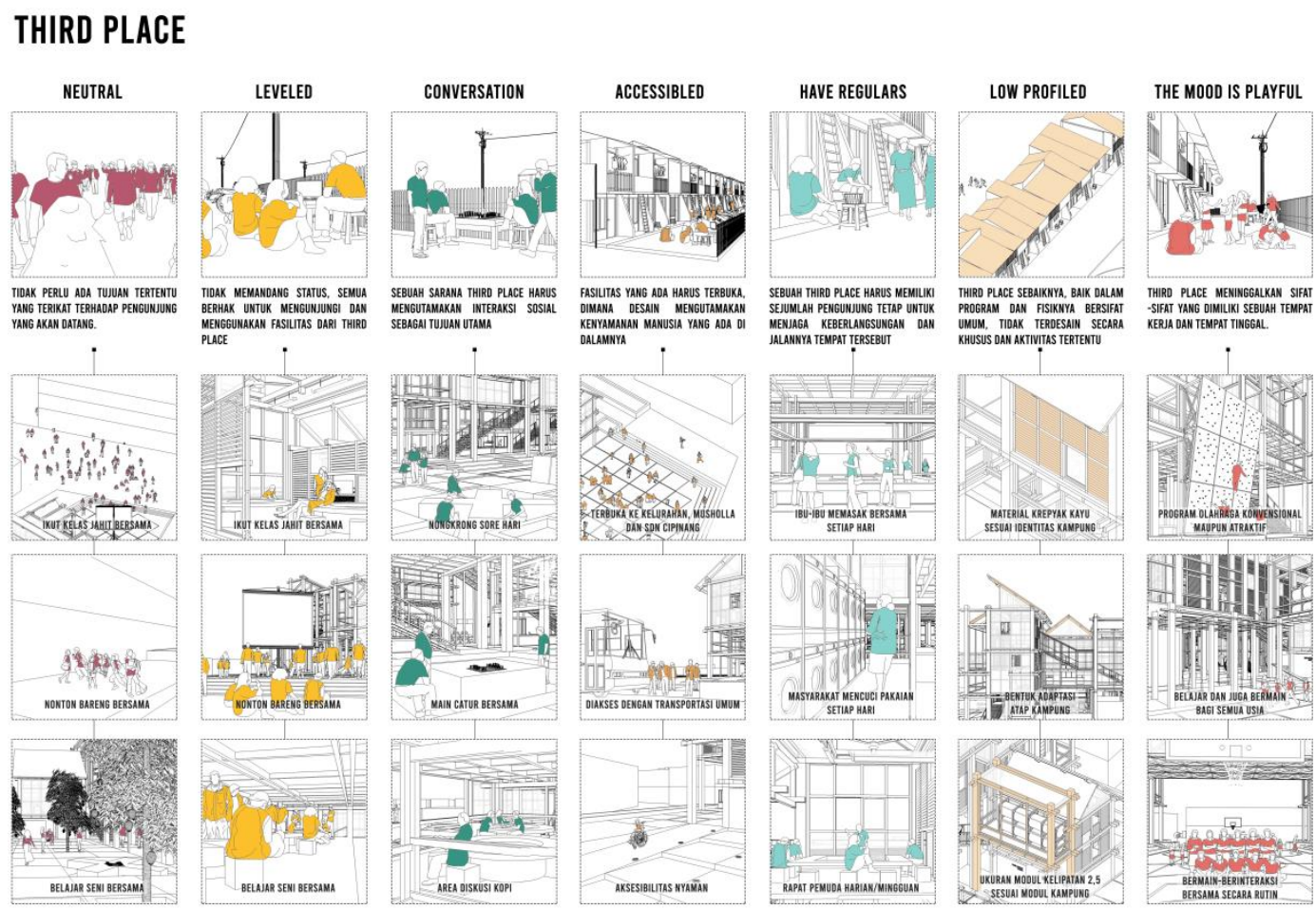

Gambar 5. Implementasi Third Place dalam Proyek

Sumber : Penulis, 2020

\section{Implementasi Sustainable Development Goals}

Implementasi terhadap lima poin dari Sustainable Development Goals diimplementasikan sebagai berikut: Good Health and Well-being, Affordable Clean Energy, Decent Work and Economic Growth, Reduced Inequalities, Sustainable Cities and Communities 

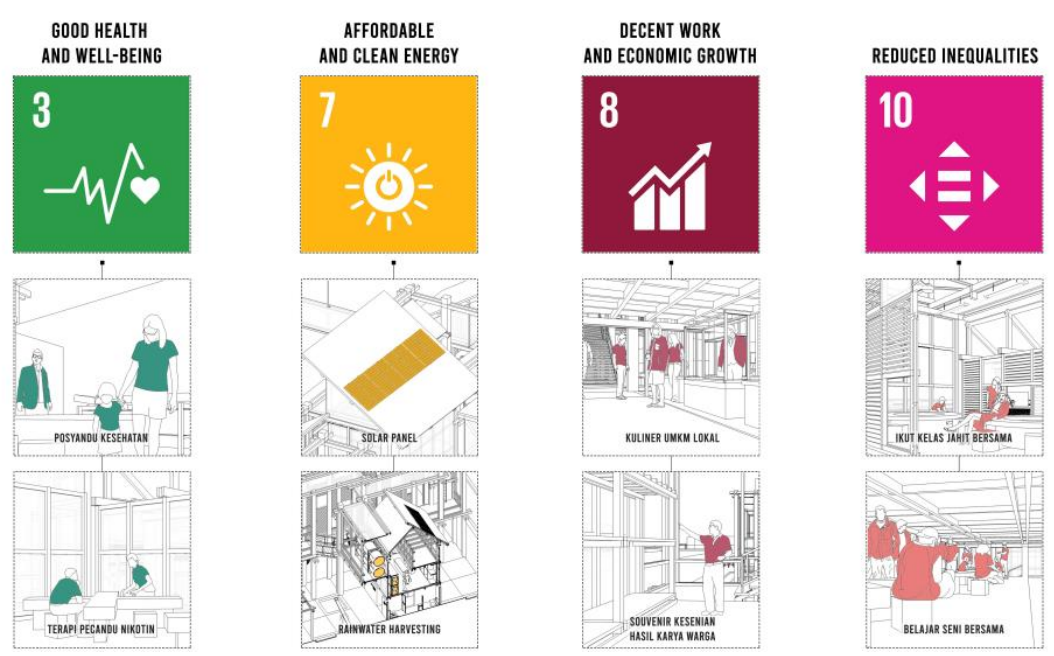

Gambar 6. Implementasi SDG dalam Proyek

Sumber: Penulis, 2020

\section{KESIMPULAN DAN SARAN}

\section{Kesimpulan}

Masyarakat Cipinang Besar Selatan memerlukan Third Place agar mereka dapat mengembangkan potensi kawasan mereka secara bersama-sama, dan Wadah Komunitas Gotong Royong telah dapat menjawab persoalan tersebut. Kehadiran Wadah Komunitas Gotong Royong mampu merespon seluruh kebutuhan masyarakat Cipinang Besar Selatan, untuk hidup ber-komunitas, secara bergotong-royong. Selain menjadi wadah dan pusat dari aktivitas, tempat ini juga menjadi sebuah wadah edukasi, agar seluruh kegiatan positif dapat tersebar secara merata di seluruh pelosok perkampungan Cipinang Besar Selatan. Bukan saja hanya menjawab per-soalan dalam kehidupan perkampungan di Cipinang Besar Selatan, namun Wadah Komunitas Gotong Royong CBS ini juga menjawab permasalhan dari Third Place itu sendiri.

\section{Saran}

Seluruh aktivitas pada Wadah Komunitas Gotong Royong CBS bersifat "dari masyarakat, untuk masyarakat", oleh sebab itu, apabila seluruh kegiatan positif yang berada pada Wadah Komunitas Gotong Royong CBS baik yang bersifat interaksi, hiburan, dan juga edukasi tidak diimplemntasikan pada wilayah perkampungan masing-masing pada kelurahan Cipinang Besar Selatan, maka seluruh esensi gotong royong dan juga esensi komunitas yang berusaha dibangun pun sia-sia. Maka dari itu disarankan agar masyarakat tetap menerapkan nilai-nilai positif di lingkungan masing-masing, agar Cipinang Besar Selatan dapat maju secara bersamasama.

\section{REFERENSI}

Oldenburgh, R. (1989). The Great Good Place. New York: Paragon House.

Tuan, Y. F. (1977). Space and Place. United States: University of Minnesota Press. 
